\title{
Failure of leptin to affect basal and insulin-stimulated glucose metabolism of rat skeletal muscle in vitro
}

\author{
C. Fürnsinn, B. Brunmair, R. Furtmüller, M. Roden, R. Englisch, W. Waldhäusl \\ Department of Medicine III, Division of Endocrinology and Metabolism, University of Vienna, Vienna, Austria.
}

\begin{abstract}
Summary Studies on different isolated tissues have provided evidence that leptin may directly modulate cellular glucose handling. The present study was performed to elucidate leptin's action on basal and insulin-stimulated glucose metabolism in native muscle tissue, which under physiological circumstances is the quantitatively most important target tissue of insulin. Isolated rat soleus muscle strips were incubated for $1 \mathrm{~h}$ in the absence or presence of leptin $(0,1,10$, or $100 \mathrm{nmol} / \mathrm{l})$ under basal or insulin-stimulated conditions $(10 \mathrm{nmol} / \mathrm{l})$. No effects of leptin were found on the rates of ${ }^{3} \mathrm{H}$-2-deoxy-glucose transport (basal: control, $314 \pm 14 ; 1 \mathrm{nmol} / 1$ leptin, $320 \pm 17 ; 10 \mathrm{nmol} / 1$ leptin, $314 \pm 13$; $100 \mathrm{nmol} / \mathrm{l}$ leptin, $322 \pm 16$; insulin-stimulated: control, $690 \pm 33 ; 1 \mathrm{nmol} / 1$ leptin, $691 \pm 29 ; 10$ $\mathrm{nmol} / 1$ leptin, $665 \pm 26 ; 100 \mathrm{nmol} / \mathrm{l}$ leptin, $664 \pm 27$; $\mathrm{cpm} \cdot \mathrm{mg}^{-1} \cdot \mathrm{h}^{-1}$; NS vs respective control) and on net glucose incorporation into glycogen (basal: control, $1.75 \pm 0.18 ; 1 \mathrm{nmol} / 1$ leptin, $2.01 \pm 0.13 ; 10 \mathrm{nmol} / 1$ lep-
\end{abstract}

tin, $1.92 \pm 0.11$; $100 \mathrm{nmol} / 1$ leptin, $1.81 \pm 0.13$; insulinstimulated: control, $5.98 \pm 0.40 ; 1 \mathrm{nmol} / 1$ leptin, $5.93 \pm 0.30 ; 10 \mathrm{nmol} / 1$ leptin, $5.46 \pm 0.25 ; 100 \mathrm{nmol} / 1$ leptin, $5.85 \pm 0.30 ; \mu \mathrm{mol} \cdot \mathrm{g}^{-1} \cdot \mathrm{h}^{-1}$; NS vs respective control). In parallel, leptin failed to affect rates of aerobic and anaerobic glycolysis as well as muscle glycogen content. Further experiments revealed that the inability of leptin to directly affect muscle glucose handling prevailed independently of muscle fiber type (soleus and epitrochlearis muscle), of ambient insulin concentrations $(0-30 \mathrm{nmol} / \mathrm{l})$, and of leptin exposure time ( $1 \mathrm{~h}$ or $6 \mathrm{~h}$ ). Thus, our findings fail to support speculations about a physiological role of direct insulin-mimetic or insulin-desensitizing effects of leptin on skeletal muscle tissue. [Diabetologia (1998) 41: 524-529]

Keywords Leptin, insulin, muscle, glucose metabolism, glucose transport, glycogen synthesis, glycolysis.
The peptide leptin is produced and released by adipocytes and exerts regulatory effects on food intake and energy expenditure [1-4]. Elevated circulating serum leptin concentrations prevail in association with increased percentage of body fat and obviously function as a humoral signal to the central nervous system triggering satiety and a decrease in food consumption $[1,5,6]$. Rats chronically treated with leptin exhibit a distinct loss of discernible body fat and markedly decreased triglyceride content of various tissues [7, 8].

Received: 7 October 1997 and in revised form: 23 January 1998

Corresponding author: C. Fürnsinn, Ph.D., Department of Medicine III, Division of Endocrinology and Metabolism, Währinger Gürtel 18-20, A-1090 Vienna, Austria
This effect is related, besides reduced food intake, to increased basal metabolic rate with selective promotion of fat metabolism $[2,3,7,8]$. Beside the brain, a variety of other tissues express specific receptors for leptin including liver, adipose tissue, skeletal muscle, and pancreatic islets [9-12], and recent evidence suggests that in addition to indirect action via the central nervous system leptin may affect fuel metabolism by direct interaction with various other tissues [7, 11-18].

Direct leptin action on isolated pancreatic rat islets includes triglyceride depletion [7] as well as distinct inhibition of glucose-stimulated insulin release $[11,13]$. Furthermore, potent inhibition by leptin of insulin's action on lipid and glucose metabolism has been demonstrated in isolated rat adipocytes [14], 
and in isolated cells of hepatic origin, acute leptin exposure has been shown to modulate early steps in intracellular insulin signal transduction [15]. With regard to glucose metabolism, however, direct leptin action on the quantitatively most important target tissue of insulin, i. e. skeletal muscle [19], is not yet fully clarified. Under basal conditions in vivo, leptin was found to distinctly stimulate whole body glucose turnover and muscle glucose uptake in mice [20], while no evidence for increased glucose turnover was observed in leptin-infused rats [21]. With regard to insulin-stimulated whole body glucose disposal, a stimulatory effect of leptin was seen only in one of two studies $[21,22]$. In vitro, leptin failed to directly affect glucose metabolism of isolated skeletal muscle from healthy mice $[12,17]$, but inhibited glycogen synthesis in muscle specimens prepared from leptindeficient obese ob/ob mice [12]. In contrast to native muscle tissue, leptin stimulated glucose transport and glycogen synthesis in cultured $\mathrm{C}_{2} \mathrm{C}_{12}$ myotubes suggesting an insulin-mimetic rather than insulin-desensitizing leptin action on myotube glucose metabolism [18].

The true potential of leptin to affect muscle glucose metabolism is therefore not yet clarified and the present study intends to further elucidate the direct action of leptin on skeletal muscle glucose metabolism. Freshly isolated rat muscle specimens were incubated in the absence or presence of leptin, and basal and insulin-stimulated rates of glucose transport, glycogen synthesis, and glycolysis were determined.

\section{Materials and methods}

Rats. Male Sprague-Dawley rats purchased from the breeding facilities of the University of Vienna (Himberg, Austria) were used and all experiments were performed according to local law and to the principles of laboratory animal care. Rats were kept at an artificial $12 \mathrm{~h}$ light/12 h dark cycle at constant room temperature and were used at fasted body weights of approximately $140 \mathrm{~g}$. Conventional laboratory diet and tap water were provided ad libitum until the evening before killing, when only food was withdrawn. Rats were killed by cervical dislocation between 08.30 and 09.30 hours.

Leptin. Recombinant mouse leptin was generously provided by Eli Lilly (Indianapolis, Ind., USA) and biological activity was confirmed by a $41 \%$ decrease in cumulative $24 \mathrm{~h}$ food intake after a single intraperitoneal injection of $125 \mu \mathrm{g}$ leptin in ob/ob mice ( $\mathrm{g}$ food consumed: control, $n=7,5.69 \pm 0.37$; vs leptin, $n=5,3.38 \pm 0.54 ; p<0.01$ by unpaired Student's $t$-test).

Incubation procedures, short-term exposure. Immediately after animals were killed, epitrochlearis muscles $(\sim 20 \mathrm{mg}$ each $)$ or two longitudinal strips of each soleus muscle ( $\sim 25 \mathrm{mg}$ each) were prepared, weighed, and tied under tension on stainless steel clips as previously described [23]. Muscles were immediately put into $25 \mathrm{ml}$ Erlenmeyer flasks coated with BlueSlick solution (Serva, Heidelberg, Germany), which were placed

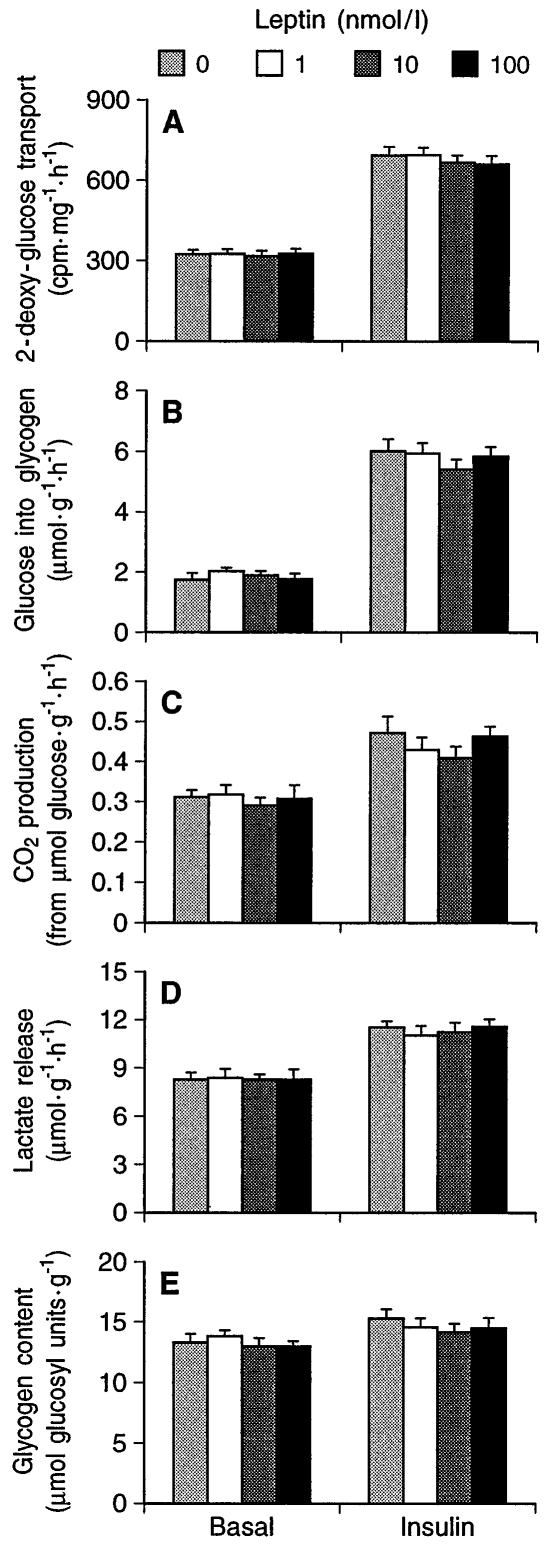

Fig. 1A-E. Effects of various leptin concentrations on muscle glucose metabolism. Basal and insulin-stimulated (0 and 10 nmol/l insulin) rates of ${ }^{3} \mathrm{H}$-2-deoxy-glucose transport (A), glucose incorporation into glycogen $(\mathbf{B})$, aerobic glycolysis $\left(\mathrm{CO}_{2}\right.$ production; C), and anaerobic glycolysis (lactate release; D) in isolated soleus muscle strips from Sprague-Dawley rats as exposed to $0,1,10$, or $100 \mathrm{nmol} / 1$ leptin; glycogen content as determined after incubation (E); means \pm SEM; $n=12-18$ each; NS for presence vs absence of leptin

into a shaking water bath $\left(1\right.$ specimen/flask; $37^{\circ} \mathrm{C} ; 130$ cycles/ min). Each flask contained $3 \mathrm{ml}$ Krebs-Henseleit buffer solution ( $\mathrm{pH} 7.35$ ) supplemented with $1 \%$ (wt/vol) bovine serum albumin and $5.5 \mathrm{mmol} / \mathrm{l}$ glucose. An atmosphere of $95 \%$ $\mathrm{O}_{2}: 5 \% \mathrm{CO}_{2}$ was continuously maintained within the flasks.

After preincubation for $30 \mathrm{~min}$ (i.e. equilibration period), muscles were immediately transferred to another set of flasks and incubated in $3 \mathrm{ml}$ of identical buffer solution containing additional tracer amounts of D-[U- $\left.{ }^{14} \mathrm{C}\right]$ glucose or, alternatively, 2-deoxy-D-[2,6- $\left.{ }^{3} \mathrm{H}\right]$ glucose plus $\left[\mathrm{U}^{14} \mathrm{C}\right]$ sucrose (all from Amersham, Amersham, UK). Where indicated, the incubation 

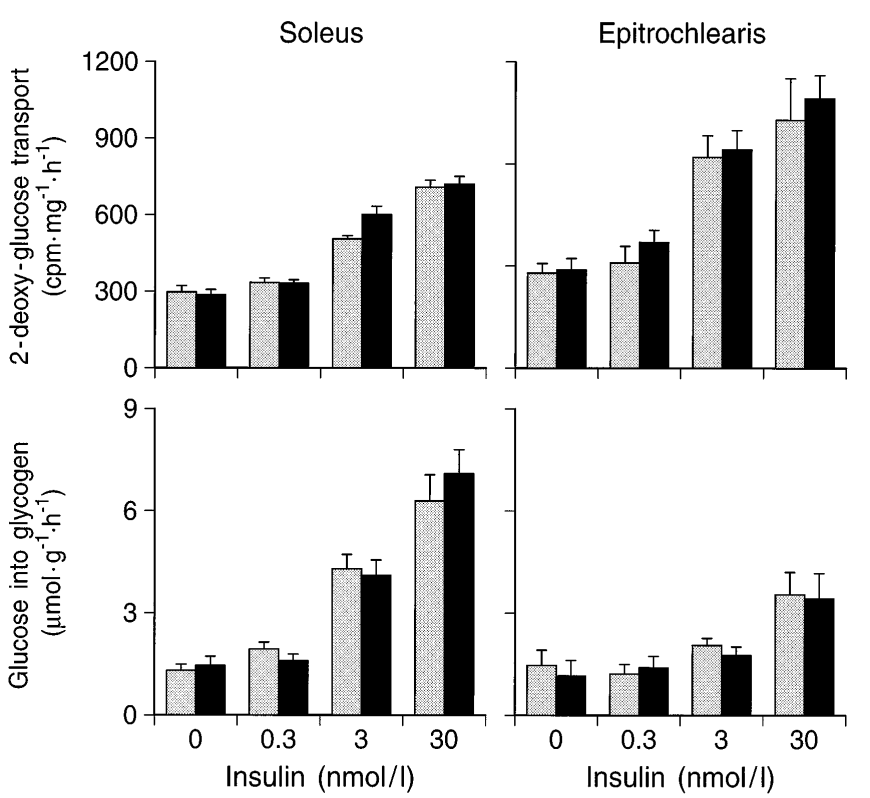

Leptin $(\mathrm{nmol} / \mathrm{l})$

50

Fig. 2. Interaction of short-term leptin exposure with skeletal muscle glucose metabolism. Effects of short-term leptin exposure $(1 \mathrm{~h}, 50 \mathrm{nmol} / \mathrm{l})$ on insulin dose-response curves $(0,0.3,3$, and $30 \mathrm{nmol} / 1$ insulin); rates of ${ }^{3} \mathrm{H}$-2-deoxy-glucose transport (upper graphs) and glucose incorporation into glycogen (lower graphs) in isolated soleus muscle (left, $n=6$ each) and epitrochlearis muscle (right; $n=3-6$ each) from Sprague-Dawley rats; means \pm SEM; NS for presence vs absence of leptin

medium contained recombinant mouse leptin $(1,10,50$, or 100 $\mathrm{nmol} / \mathrm{l}$ ) and/or human insulin (Actrapid; Novo, Bagsvaerd, Denmark; $0.3,3,10$, or $30 \mathrm{nmol} / \mathrm{l})$. After incubation for $60 \mathrm{~min}$, muscles were quickly removed, blotted, and frozen in liquid nitrogen. Later, muscle strips were lysed in $1 \mathrm{~mol} / \mathrm{l}$ $\mathrm{KOH}$ at $70^{\circ} \mathrm{C}$, the lysate was then employed for further analytical procedures as described below.

Incubation procedures, long-term exposure. The preincubation procedure was started as for acute exposure experiments, except that muscles were put into coated $50 \mathrm{ml}$-flasks containing $20 \mathrm{ml}$ cell culture medium 199 (Sigma, Cat. No. M-4530; pH $7.35 ; 6$ specimens/flask) additionally supplemented with $1 \%$ (wt/vol) bovine serum albumin, $5 \mathrm{mmol} / \mathrm{l}$ HEPES, $25000 \mathrm{U} / 1$ penicillin $\mathrm{G}, 25 \mathrm{mg} / \mathrm{l}$ streptomycin, and where indicated 50 nmol/l leptin. After preincubation for $5 \mathrm{~h}$, muscles were immediately transferred into a set of $25 \mathrm{ml}$ flasks (1 specimen/flask) and incubated for $1 \mathrm{~h}$ in $3 \mathrm{ml}$ of identical buffer solution containing 0,3 , or $30 \mathrm{nmol} / \mathrm{l}$ insulin. Tracer addition and all further procedures were as described for short-term exposure experiments. Muscle preparations have been demonstrated previously to remain viable and insulin-responsive up to $24 \mathrm{~h}$ under these experimental conditions [24].

Analytical procedures. All analytical procedures were performed as described previously $[23,25]$. In short, the transport rate of 2-deoxy-D-[2,6- $\left.{ }^{3} \mathrm{H}\right]$ glucose, a glucose analogue which does not enter glycolysis and hence accumulates within the cell, was determined employing $\left[{ }^{14} \mathrm{C}\right]$ sucrose as an extracellular space marker [25]. Net rates of glucose incorporation into glycogen are referred to as glycogen synthesis and were deter-
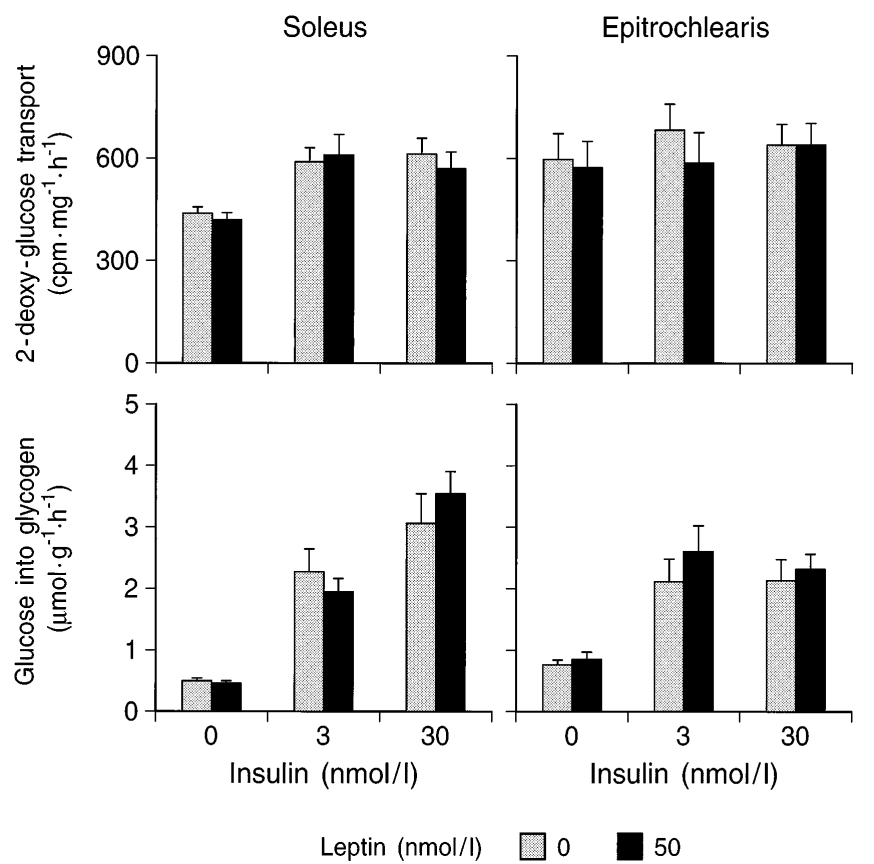

Fig.3. Interaction of long-term leptin exposure with skeletal muscle glucose metabolism. Effects of long-term leptin exposure $(6 \mathrm{~h}, 50 \mathrm{nmol} / \mathrm{l})$ on insulin dose-response curves $(0,3$, and $30 \mathrm{nmol} / \mathrm{l}$ insulin); rates of ${ }^{3} \mathrm{H}$-2-deoxy-glucose transport (upper graphs) and glucose incorporation into glycogen (lower graphs) in isolated soleus muscle (left, $n=6-8$ each) and epitrochlearis muscle (right; $n=5-10$ each) from Sprague-Dawley rats; means \pm SEM; NS for presence vs absence of leptin

mined by measuring conversion of $\left[{ }^{14} \mathrm{C}\right]$ glucose to $\left[{ }^{14} \mathrm{C}\right]$ glycogen $[23,25]$. Rates of $\mathrm{CO}_{2}$ production were calculated from conversion of $\left[{ }^{14} \mathrm{C}\right]$ glucose into ${ }^{14} \mathrm{CO}_{2}$, which was trapped with solution containing methanol and phenethylamine (1:1) [25]. Rates of lactate release were determined by measuring lactate accumulated in the incubation buffer during the experiment [25]. For the determination of muscle glycogen content, glycogen in the muscle lysate was completely degraded to glucose with amyloglucosidase [25]. Glucose was then measured enzymatically using a commercial kit from Human (Taunusstein, Germany).

Statistical analysis. All data are presented as means \pm SEM and leptin action was evaluated by intraindividual comparison of muscle specimens obtained from the same rat. Paired Student's $t$-test was employed for comparison of two groups, while multiple comparisons compared to the same control were performed according to the method of Dunnett [26]. A $p$ value less than 0.05 was considered significant.

\section{Results}

Acute exposure of freshly isolated soleus muscle strips to leptin as added to the incubation buffer at concentrations of 1,10 , or $100 \mathrm{nmol} / \mathrm{l}$ did not exert any significant effect on the determined parameters of basal or insulin-stimulated glucose metabolism, which included rates of ${ }^{3} \mathrm{H}$-2-deoxy-glucose trans- 
Table 1. Interaction of short-term leptin exposure with skeletal muscle glucose metabolism

\begin{tabular}{|c|c|c|c|c|c|c|c|c|c|}
\hline \multirow{2}{*}{$\frac{\text { Insulin (nmol/l) }}{\text { Leptin (nmol/l) }}$} & & \multicolumn{2}{|l|}{0} & \multicolumn{2}{|l|}{0.3} & \multicolumn{2}{|l|}{3} & \multicolumn{2}{|l|}{30} \\
\hline & & 0 & 50 & 0 & 50 & 0 & 50 & 0 & 50 \\
\hline $\begin{array}{l}\text { Soleus muscle } \\
\mathrm{CO}_{2} \\
\text { Release, } \\
\left(\mathrm{nmol} \text { glucose } \cdot \mathrm{g}^{-1} \cdot \mathrm{h}^{-1}\right)\end{array}$ & $n$ & $\begin{array}{l}6 \\
344 \pm 17\end{array}$ & $\begin{array}{l}6 \\
347 \pm 48\end{array}$ & $\begin{array}{l}6 \\
359 \pm 34\end{array}$ & $\begin{array}{l}6 \\
325 \pm 27\end{array}$ & $\begin{array}{l}6 \\
261 \pm 20\end{array}$ & $\begin{array}{l}6 \\
302 \pm 18\end{array}$ & $\begin{array}{l}6 \\
350 \pm 37\end{array}$ & $\begin{array}{l}6 \\
311 \pm 10\end{array}$ \\
\hline $\begin{array}{l}\text { Lactate } \\
\text { Release, } \\
\left(\mu \mathrm{mol} \cdot \mathrm{g}^{-1} \cdot \mathrm{h}^{-1}\right)\end{array}$ & $n$ & $\begin{array}{l}6 \\
8.0 \pm 0.8\end{array}$ & $6.3 \pm 0.1$ & $\begin{array}{l}6 \\
7.0 \pm 0.5\end{array}$ & $\begin{array}{l}6 \\
6.8 \pm 0.5\end{array}$ & $\begin{array}{l}6 \\
9.3 \pm 0.5\end{array}$ & $\begin{array}{l}6 \\
9.7 \pm 0.6\end{array}$ & $\begin{array}{l}6 \\
11.3 \pm 0.7\end{array}$ & $\begin{array}{l}6 \\
12.1 \pm 1.0\end{array}$ \\
\hline $\begin{array}{l}\text { Glycogen } \\
\text { Content, } \\
\left(\mu \mathrm{mol} \text { glucosyl units } \cdot \mathrm{g}^{-1}\right)\end{array}$ & $n$ & $\begin{array}{l}6 \\
9.8 \pm 0.3\end{array}$ & $\begin{array}{l}6 \\
10.2 \pm 0.5\end{array}$ & $\begin{array}{l}6 \\
10.3 \pm 0.7\end{array}$ & $\begin{array}{l}6 \\
10.1 \pm 0.6\end{array}$ & $\begin{array}{l}6 \\
12.2 \pm 0.9\end{array}$ & $\begin{array}{l}6 \\
11.6 \pm 0.4\end{array}$ & $\begin{array}{l}6 \\
11.9 \pm 1.0\end{array}$ & $\begin{array}{l}6 \\
12.6 \pm 1.3\end{array}$ \\
\hline $\begin{array}{l}\text { Epitrochlearis muscle } \\
\mathrm{CO}_{2} \\
\text { Release, } \\
\left(\text { nmol glucose } \cdot \mathrm{g}^{-1} \cdot \mathrm{h}^{-1}\right)\end{array}$ & $n$ & $\begin{array}{l}5 \\
582 \pm 100\end{array}$ & $\begin{array}{l}5 \\
413 \pm 42\end{array}$ & $\begin{array}{l}5 \\
529 \pm 82\end{array}$ & $\begin{array}{l}5 \\
584 \pm 139\end{array}$ & $\begin{array}{l}5 \\
892 \pm 212\end{array}$ & $\begin{array}{l}5 \\
734 \pm 234\end{array}$ & $\begin{array}{l}5 \\
1068 \pm 163\end{array}$ & $\begin{array}{l}5 \\
950 \pm 256\end{array}$ \\
\hline $\begin{array}{l}\text { Lactate } \\
\text { Release, } \\
\left(\mu \mathrm{mol} \cdot \mathrm{g}^{-1} \cdot \mathrm{h}^{-1}\right)\end{array}$ & $n$ & $\begin{array}{l}6 \\
9.7 \pm 1.7\end{array}$ & $\begin{array}{l}6 \\
9.9 \pm 0.9\end{array}$ & $\begin{array}{l}6 \\
10.6 \pm 0.7\end{array}$ & $\begin{array}{l}6 \\
11.4 \pm 1.7\end{array}$ & $\begin{array}{l}6 \\
13.5 \pm 1.4\end{array}$ & $\begin{array}{l}6 \\
13.5 \pm 1.7\end{array}$ & $\begin{array}{l}3 \\
16.1 \pm 2.5\end{array}$ & $\begin{array}{l}3 \\
15.8 \pm 2.6\end{array}$ \\
\hline $\begin{array}{l}\text { Glycogen } \\
\text { Content, } \\
\left(\mu \mathrm{mol} \text { glucosyl units } \cdot \mathrm{g}^{-1}\right)\end{array}$ & $n$ & $\begin{array}{l}5 \\
10.8 \pm 0.8\end{array}$ & $\begin{array}{l}5 \\
11.2 \pm 0.9\end{array}$ & $\begin{array}{l}6 \\
12.0 \pm 1.2\end{array}$ & $\begin{array}{l}6 \\
12.0 \pm 0.6\end{array}$ & $\begin{array}{l}5 \\
12.4 \pm 1.6\end{array}$ & $\begin{array}{l}5 \\
11.0 \pm 1.1\end{array}$ & $\begin{array}{l}6 \\
12.4 \pm 0.5\end{array}$ & $\begin{array}{l}6 \\
13.1 \pm 1.3\end{array}$ \\
\hline
\end{tabular}

Effects of short-term leptin exposure $(1 \mathrm{~h}, 50 \mathrm{nmol} / \mathrm{l})$ on insulin dose-response curves $(0,0.3,3$, and $30 \mathrm{nmol} / 1$ insulin); rates of $\mathrm{CO}_{2}$ production and lactate release in isolated soleus muscle

port, glycogen synthesis, aerobic glycolysis (i.e. $\mathrm{CO}_{2}$ production), anaerobic glycolysis (i.e. lactate release), and glycogen content as determined after the experiment (Fig. 1).

Likewise, $50 \mathrm{nmol} / \mathrm{l}$ leptin failed to affect glucose metabolism in isolated soleus muscle as well as in isolated epitrochlearis muscle exposed to insulin concentrations ranging from 0.3 to $30 \mathrm{nmol} / \mathrm{l}$ (Fig. 2, Table 1) or exposed to leptin for a prolonged time period of 6 h (Fig. 3, Table 2).

\section{Discussion}

Exposure to leptin in vitro has been shown to decrease the phosphorylation/activation of the insulin receptor subunit- $\beta$ and of insulin receptor substrate1 in isolated cells of hepatic origin as well as in rat-1 fibroblasts overexpressing the human insulin receptor $[15,16]$ and more recently, a very distinct potential of leptin to inhibit the metabolic effects of insulin was reported for isolated adipocytes [14]. Based on these findings, a role for leptin in the natural development of obesity-associated insulin resistance was hypothesized [14-16, 18].

The quantitatively most important target tissue for insulin with regard to glucose metabolism, however, is skeletal muscle [19] and the present study was performed to elucidate the potential role of direct interaction of leptin with skeletal muscle glucose handling. Muscle preparations employed in this study re- and epitrochlearis muscle from Sprague-Dawley rats; glycogen content as determined after incubation; means \pm SEM; NS for presence vs absence of leptin

sponded well to insulin, but no effects of short- or long-term leptin exposure were observed on the rates of basal and insulin-stimulated 2-deoxy-glucose transport, glycogen synthesis, $\mathrm{CO}_{2}$ production, and lactate release. Our experiments were designed to cover basal and partially as well as maximally insulin-stimulated conditions, but leptin neither influenced insulin-independent glucose metabolism nor did it affect insulin sensitivity or insulin responsiveness. Because leptin's potential to modulate glucose metabolism may depend on muscle fiber type, we further tested leptin action on muscle specimens of both soleus muscle (red muscle, mainly type I fibers) and epitrochlearis muscle (white muscle, mainly type II fibers) [27]. A leptin concentration of $50 \mathrm{nmol} / \mathrm{l}$, which has been found to blunt insulin's stimulatory effect on 2-deoxy-glucose transport in adipocytes with a $40 \%$ decrease observed after $30 \mathrm{~min}$ and nearly complete abolition after $5 \mathrm{~h}$ [14], lacked any influence on muscle glucose metabolism independent of muscle fiber type and prevailing insulin concentration.

It must be emphasized that the absence of direct leptin action on isolated native muscle does not exclude an indirect effect of leptin on muscle glucose handling in vivo as potentially mediated via leptin interaction with the central nervous system $[1,6,20]$, liver [15, 21], adipose tissue [14], or pancreas [7, 11, 13]. Recently, a nervous mode of action was indicated in that leptin-stimulated glucose uptake into skeletal muscle was found to be abolished by muscle denerva- 
Table 2. Interaction of long-term leptin exposure with skeletal muscle glucose metabolism

\begin{tabular}{|c|c|c|c|c|c|c|c|}
\hline \multirow{2}{*}{$\begin{array}{l}\text { Insulin (nmol/l) } \\
\text { Leptin }(\mathrm{nmol} / \mathrm{l})\end{array}$} & & \multicolumn{2}{|l|}{0} & \multicolumn{2}{|l|}{3} & \multicolumn{2}{|l|}{30} \\
\hline & & 0 & 50 & 0 & 50 & 0 & 50 \\
\hline $\begin{array}{l}\text { Soleus muscle } \\
\mathrm{CO}_{2} \\
\text { Release, } \\
\left(\mathrm{nmol} \text { glucose } \cdot \mathrm{g}^{-1} \cdot \mathrm{h}^{-1}\right)\end{array}$ & $n$ & $\begin{array}{l}8 \\
693 \pm 62\end{array}$ & $\begin{array}{l}8 \\
644 \pm 64\end{array}$ & $\begin{array}{l}6 \\
969 \pm 117\end{array}$ & $\begin{array}{l}6 \\
793 \pm 44\end{array}$ & $\begin{array}{l}6 \\
1081 \pm 71\end{array}$ & $\begin{array}{l}6 \\
1012 \pm 45\end{array}$ \\
\hline $\begin{array}{l}\text { Lactate } \\
\text { Release, } \\
\left(\mu \mathrm{mol} \cdot \mathrm{g}^{-1} \cdot \mathrm{h}^{-1}\right)\end{array}$ & $n$ & $\begin{array}{l}6 \\
11.6 \pm 0.8\end{array}$ & $\begin{array}{l}6 \\
10.9 \pm 0.6\end{array}$ & $\begin{array}{l}6 \\
13.8 \pm 0.9\end{array}$ & $\begin{array}{l}6 \\
15.2 \pm 1.0\end{array}$ & $\begin{array}{l}6 \\
13.9 \pm 1.1\end{array}$ & $\begin{array}{l}6 \\
13.0 \pm 0.5\end{array}$ \\
\hline $\begin{array}{l}\text { Glycogen } \\
\text { Content, } \\
\left(\mu \mathrm{mol} \text { glucosyl units } \cdot \mathrm{g}^{-1}\right)\end{array}$ & $n$ & $\begin{array}{l}8 \\
11.0 \pm 0.7\end{array}$ & $\begin{array}{l}8 \\
10.5 \pm 0.5\end{array}$ & $\begin{array}{l}6 \\
12.1 \pm 0.6\end{array}$ & $\begin{array}{l}6 \\
10.7 \pm 0.4\end{array}$ & $\begin{array}{l}6 \\
13.7 \pm 1.1\end{array}$ & $\begin{array}{l}6 \\
12.4 \pm 1.5\end{array}$ \\
\hline $\begin{array}{l}\text { Epitrochlearis muscle } \\
\mathrm{CO}_{2} \\
\text { Release, } \\
\left(\mathrm{nmol} \text { glucose } \cdot \mathrm{g}^{-1} \cdot \mathrm{h}^{-1}\right)\end{array}$ & $n$ & $\begin{array}{l}4 \\
1166 \pm 139\end{array}$ & $\begin{array}{l}4 \\
1085 \pm 82\end{array}$ & $\begin{array}{l}6 \\
1190 \pm 151\end{array}$ & $\begin{array}{l}6 \\
1136 \pm 189\end{array}$ & $\begin{array}{l}10 \\
1216 \pm 101\end{array}$ & $\begin{array}{l}10 \\
1343 \pm 102\end{array}$ \\
\hline $\begin{array}{l}\text { Lactate } \\
\text { Release, } \\
\left(\mu \mathrm{mol} \cdot \mathrm{g}^{-1} \cdot \mathrm{h}^{-1}\right)\end{array}$ & $n$ & $\begin{array}{l}8 \\
12.4 \pm 1.1\end{array}$ & $\begin{array}{l}8 \\
13.2 \pm 1.1\end{array}$ & $\begin{array}{l}6 \\
13.9 \pm 1.1\end{array}$ & $\begin{array}{l}6 \\
13.0 \pm 0.5\end{array}$ & $\begin{array}{l}5 \\
15.0 \pm 1.6\end{array}$ & $\begin{array}{l}5 \\
14.0 \pm 1.4\end{array}$ \\
\hline $\begin{array}{l}\text { Glycogen } \\
\text { Content, } \\
\left(\mu \mathrm{mol} \text { glucosyl units } \cdot \mathrm{g}^{-1}\right)\end{array}$ & $n$ & $\begin{array}{l}5 \\
8.0 \pm 1.6\end{array}$ & $\begin{array}{l}5 \\
7.1 \pm 1.1\end{array}$ & $\begin{array}{l}6 \\
11.9 \pm 0.6\end{array}$ & $\begin{array}{l}6 \\
13.7 \pm 2.0\end{array}$ & $\begin{array}{l}10 \\
10.3 \pm 1.2\end{array}$ & $\begin{array}{l}10 \\
11.0 \pm 1.0\end{array}$ \\
\hline
\end{tabular}

Effects of long-term leptin exposure $(6 \mathrm{~h}, 50 \mathrm{nmol} / \mathrm{l})$ on insulin dose-response curves $(0,3$, and $30 \mathrm{nmol} / 1$ insulin $)$; rates of $\mathrm{CO}_{2}$ production and lactate release in isolated soleus muscle and epitrochlearis muscle from Sprague-Dawley rats; glycogen content as determined after incubation; means \pm SEM; NS for presence vs absence of leptin tion [20]. Taken together, our results fail to provide any evidence for direct effects of leptin on healthy rat muscle glucose handling, in line with the recently reported lack of leptin-dependent modulation of glucose metabolism in isolated mouse soleus and extensor digitorum longus muscles $[12,17]$.

Contrary to our observations in native muscle tissue, exposure of $\mathrm{C}_{2} \mathrm{C}_{12}$ myotubes to a leptin concentration of only $1 \mathrm{ng} / \mathrm{ml}$ (approximately $0.06 \mathrm{nmol} / \mathrm{l}$ ) for $1 \mathrm{~h}$ insulin-independently stimulated the rates of glucose transport ( $84 \%$ of the insulin effect) and glycogen synthesis ( $38 \%$ of the insulin effect), while no effect was seen in the presence of insulin [18]. Failure to document any insulin-mimetic leptin action in isolated rat soleus or epitrochlearis muscles therefore suggests major differences in the interaction of leptin with $\mathrm{C}_{2} \mathrm{C}_{12}$ myotubes compared to native muscle tissue, whereby the experimental approach used in our study is more closely related to the physiological situation than myotube culture.

In conclusion, leptin exposure for $1 \mathrm{~h}$ and for $6 \mathrm{~h}$ failed to directly modulate rates of basal and insulinstimulated glucose metabolism in isolated rat skeletal muscles of different fiber types. Therefore, if they take place under physiological conditions, shortterm leptin-dependent changes in muscle glucose handling must depend on an indirect mode of action involving the central nervous system, liver, pancreatic islets, and/or adipose tissue.
Acknowledgements. We appreciate the help of the staff at the Biomedical Research Center, University of Vienna, for taking care of the rats. Recombinant mouse leptin was generously supplied by Eli Lilly (Indianapolis, IN). This work was supported by the Austrian Science Fund, Grant No. P11403MED and, to M. R., Grant No.P10416-MED.

\section{References}

1. Caro JF, Madhur MK, Kolaczynski JW, Zhang PL, Considine RV (1996) Leptin: the tale of an obesity gene. Diabetes 45: $1455-1462$

2. Pelleymounter MA, Cullen MJ, Baker MB, Hecht R, Winters D, Boone T, Collins F (1995) Effects of the obese gene product on body weight regulation in ob/ob mice. Science 269: 540-543

3. Levin N, Nelson C, Gurney A, Vandlen R, de Sauvage F (1996) Decreased food intake does not completely account for adiposity reduction after ob protein infusion. Proc Natl Acad Sci USA 93: 1726-1730

4. Hwa JJ, Fawzi AB, Graziano MP et al. (1997) Leptin increases energy expenditure and selectively promotes fat metabolism in ob/ob mice. Am J Physiol 272: R1204R1209

5. Considine RV, Sinha MK, Heiman ML et al. (1995) Serum immunoreactive-leptin concentrations in normal weight and obese humans. N Engl J Med 334: 292-295

6. Jacob RJ, Dziura J, Medwick MB et al. (1997) The effect of leptin is enhanced by microinjection into the ventromedial hypothalamus. Diabetes 46: 150-152

7. Shimabukuro M, Koyama K, Chen G et al. (1997) Direct antidiabetic effect of leptin through triglyceride depletion of tissues. Proc Natl Acad Sci USA 94: 4637-4641 
8. Chen G, Koyama K, Yuan X et al. (1996) Disappearance of body fat in normal rats induced by adenovirus-mediated leptin gene therapy. Proc Natl Acad Sci USA 93: 14795-14799

9. Lee G-H, Proenca R, Montez JM et al. (1996) Abnormal splicing of the leptin receptor in diabetic mice. Nature 379: 632-635

10. Cioffi JA, Shafer AW, Zupancic TJ et al. (1996) Novel B219/OB receptor isoforms: possible role of leptin in hematopoiesis and reproduction. Nature Medicine 2: 585-589

11. Emilsson V, Liu Y-L, Cawthorne MA, Morton NM, Davenport M (1997) Expression of the functional leptin receptor mRNA in pancreatic islets and direct inhibitory action of leptin on insulin secretion. Diabetes 46: 313-316

12. Liu Y-L, Emilsson V, Cawthorne MA (1997) Leptin inhibits glycogen synthesis in the isolated soleus muscle of obese (ob/ob) mice. FEBS Letters 411: 351-355

13. Kieffer TJ, Heller S, Leech CA, Holz GG, Habener JF (1997) Leptin suppression of insulin secretion by the activation of ATP-sensitive $\mathrm{K}^{+}$channels in pancreatic $\beta$-cells. Diabetes 46: 1087-1093

14. Müller G, Ertl J, Gerl M, Preibisch G (1997) Leptin impairs metabolic actions of insulin in isolated rat adipocytes. J Biol Chem 272: 10585-10593

15. Cohen B, Novick D, Rubinstein M (1996) Modulation of insulin activities by leptin. Science 274: 1185-1188

16. Kroder G, Kellerer M, Häring HU (1996) Effect of leptin on insulin signalling in rat-1 fibroblasts overexpressing HIR. Exp Clin Endocrinol Diabetes 104 [Suppl 2]: 66 (Abstract)

17. Muoio DM, Dohn GL, Fiedorek FT, Tapscott EB, Coleman RA (1997) Leptin directly alters lipid partitioning in skeletal muscle. Diabetes 46: 1360-1363
18. Berti L, Kellerer M, Capp E, Häring HU (1997) Leptin stimulates glucose transport and glycogen synthesis in $\mathrm{C}_{2} \mathrm{C}_{12}$ myotubes: evidence for a PI3-kinase mediated effect. Diabetologia 40: 606-609

19. Baron AD, Brechtel G, Wallace P, Edelman SV (1988) Rates and tissue sites of non-insulin- and insulin-mediated glucose uptake in humans. Am J Physiol 255: E769-E774

20. Kamohara S, Burcellin R, Halaas JL, Friedman JM, Charron MJ (1997) Acute stimulation of glucose metabolism in mice by leptin treatment. Nature 389: 374-377

21. Rossetti L, Massilon D, Barzilai N et al. (1997) Short term effects of leptin on hepatic gluconeogenesis and in vivo insulin action. J Biol Chem 272: 27758-27763

22. Sivitz WI, Walsh SA, Morgan DA, Thomas MJ, Haynes WG (1997) Effects of leptin on insulin sensitivity in normal rats. Endocrinology 138: 3395-3401

23. Crettaz M, Prentki M, Zanietti D, Jeanrenaud B (1980) Insulin resistance in soleus muscle from obese Zucker rats. Involvement of several defective sites. Biochem J 186: 525-534

24. Fürnsinn C, Neschen S, Wagner O, Roden M, Bisschop M, Waldhäusl W (1997) Acute and chronic exposure to tumor necrosis factor- $\alpha$ fails to affect insulin-stimulated glucose metabolism of isolated rat soleus muscle. Endocrinology 138: 2674-2679

25. Fürnsinn C, Ebner K, Waldhäusl W (1995) Failure of GLP1(7-36)amide to affect glycogenesis in rat skeletal muscle. Diabetologia 38: 864-867

26. Dunnett CW (1964) New tables for multiple comparisons with a control. Biometrics 290: 482-491

27. Dyck DJ, Peters SJ, Glatz J et al. (1997) Functional differences in lipid metabolism in resting skeletal muscle of various fiber types. Am J Physiol 272: E340-E351 